\title{
Regional Human Capital Development Policy and
}

\section{Sandwich-Placement Training in Higher Education: Lessons Learned From the Pioneering Example of the University of Corsica in a Small Island Economy}

\author{
Christophe Storaï, Laetitia Rinieri \\ University of Corsica, Corte, France
}

\begin{abstract}
The world is changing, compelling higher education and research institutions to change too-as vectors of knowledge production and transfer, they are torn between a classic mission (educating students) and a more proactive function (developing and preparing students to enter the job market), both of which struggle to accommodate today's new economic paradigms. However, higher education - and especially university teaching - cannot coherently, let alone deterministically, fit "training/schooling" to "job/activity". Employment and the job market, are changing quantitatively and qualitatively, and coherent policy of coordinated interventions from the State, the Corsica Regional Council, employer and employee organizations, and the other institutional, economic and social community players are vital to deliver efficient and top-quality services to offer spanning information, guidance, lifelong learning, job-to-education fit, cultivating competencies, and leveraging human resources - all both region-wide and at areal level. Over the last few years, the higher education and research landscape have had to contend with some big changes. The University of Corsica-a major component in the island-region's higher education and research ecosystem - only recently secured a new status as autonomous independent university, under the French "LRU" University Autonomy and Accountabilities reform of 10 August 2007. That said, through legislation passed on 13 May 1991 and bolstered by the later decentralization law of 22 January 2002, the CTC (Corsica-region local government) enjoys a wider set of prerogatives on higher education and research development policy than anywhere else in France. After highlighting the specific features of University of Corsica's sandwich training programme as pivotal to Corsica island's Regional Vocational Development Programme Roadmap (CPRDF) strategy, this paper presents an analysis of the lessons learned from the experience of the University of Corsica as a dynamic shaper of regional human capital development policy.
\end{abstract}

Keywords: higher education, sandwich training, human capital, school-to-work transition, areal development policy, structuring the socio-economic fabric of Corsica

Christophe Storaï, senior lecturer in economics and director of the Corsica-region University-sponsored Placements \& Apprenticeships Service (CFA UNIV), University Institute of Technology of Corsica (IUT), University of Corsica, Corte, France. Laetitia Rinieri, vocational training and school-to-work transition engineer, Corsica-region University-sponsored Placements \& Apprenticeships Service (CFA UNIV), Campus Grimaldi, Bât PPDB, University of Corsica, Corte, France.

Correspondence concerning this article should be addressed to Christophe Storaï, CFA UNIV en region Corse, Campus Grimaldi, Bât PPDB, Université de Corse, 20250 Corte, France. 


\section{Introduction}

The French "LRU" University Autonomy and Accountabilities reform of 10 August 2007 makes vocational readiness and school-to-work transition core public service policy missions for higher education. Under LRU law, all higher education institutions are required to publish a number of statistics, including indicators on career placement rates.

Over the last few years, the higher education and research landscape have thus had to contend with some big changes. In tandem, the University of Corsica - a major component in the island-region's higher education and research ecosystem - secured a new status as autonomous independent university in January 2009.

This new status brought a broader scope of missions, with the traditional missions tied to educating, training, and transferring knowledge and competencies extended to also encompass registering and onboarding new students and coaching them on their personal and professional career plan through successful completion, i.e., gaining the degree/vocational certificate and making the school-to-work transition.

That said, through legislation passed on 13 May 1991 and bolstered by the later decentralization law of 22 January $2002^{1}$, the CTC (Corsica-region local government) enjoys a wider set of prerogatives on higher education and research development policy than anywhere else in France.

Given this new landscape, the CTC and the University of Corsica were elected to revamp their partnership and develop vocational training in higher education, chiefly through continuing professional education and apprenticeship schemes. Moving towards this goal, the challenge to make higher education an economic sector in itself, turning its knowledge and know-how into an exportable asset is now championed as a major driver of regional development strategy for the island's economy by everyone involved.

With the pace of disruptive change in technologies, jobs, and the workplace outside Corsica, and with a deeper structural social and economic crisis hitting some sectors inside Corsica harder, the CTC proned a move to position the University of Corsica as lead coordinator for cooperation across all of the island's higher education infrastructure under pressure to professionalize the vocational training offer - and thus adapt and align to the job market.

The strategy frameworking of Corsica island's 2011-2015 Regional Vocational Development Programme Roadmap (CPRDF) included championing a policy of investment in human capital as a key foundation of a compelling regional brand, capable of shaping and selling the most vital valued assets that typify a regional territory emerging into a structured destination-brand identity (simultaneous growth in the employability and quality of school-to-work transition shown by its human capital, mass shift in the degree of skill acquisition directly tied to the regional territory's own organic needs, fluidity of knowledge transfer fully controlled through sandwich placements, deep sustainable entrepreneurship education, and so on).

This is where educational training strategies are a particularly key factor for spurring the availability of skilled qualified human resources and unlocking innovative high-potential entrepreneurship (Marchesnay, Kammoun, \& Karray, 2006). Extending on this idea, localized productive ecosystems-built on the competitiveness clusters model founded on core tech research, and engineered with SMEs well engaged in the governance framework-offer a potential source of sustainable regional-level structural planning and development (Veltz, 1997; Colletis \& Pecqueur, 1996).

1 See French decentralization policy on Corsica passed into law on 22 January 2002 : http://www.legifrance.gouv.fr/affichTexte.do?cidTexte=JORFTEXT000000409466\&categorieLien=id. 
The paper brings an analysis of the lessons learned from the pioneering example of the University of Corsica as a dynamic shaper of regional human capital development policy. The findings of Ministry-sponsored surveys on the transition-to-work track record of University of Corsica graduates since 2011 are analyzed to gain key learnings on job-to-training fit and structured entrepreneurial fabric in Corsica.

\section{Specific Features of University of Corsica's Sandwich Training Programme as Pivotal to Corsica Island's CPRDF Strategy}

The national vocational training system was in need of reform, and a bill was passed on 6 March 2014. This new law on vocational training, employment, and social democracy sets out the powers and authorities devolved to each agency and gives the region lead role in training and apprenticeship policy. Central government continues to hold authority over employment policy, while responsibility for youth and adult vocational training policy and strategy is devolved down to the regions. Employee training remains the remit of collective bargaining and labour relations. All these players are engaged in employment protection and career security measures, and all need to cooperate to organize lifelong learning and training opportunities.

This reform puts the final seal on the vocational training strand of the decentralization process, empowering the regions to deliver more cohesive actions putting them at the forefront of vocational training policy. New powers and accountabilities have been devolved down to the regions, chief of which:

- training opportunities for special populations (prisoners, people with disabilities, and expatriates);

- training services to help jobseekers get into work;

- funding working tax credit for all unpaid jobseekers and interns in vocational training; support and guidance to candidates for Accreditation of Prior Experiential Learning (APEL);

- designing and coordinating apprenticeship training agreements;

- a voice in how money raised by the apprenticeships levy gets spent.

The region has now become the most relevant geographic and legislative space for building training path policy - and in Corsica, the CTC emerges as the sponsor of a coherent and cohesive region-wide.

\section{Objectives of the CTC-led CPRDF for Corsica}

In a good governance, effort is designed to organizationally frame its powers under the specific prerogatives granted, the Collectivité Territoriale de Corse-Corsica-region's local government council, in line with the island's Regional Vocational Development Programme Roadmap (CPRDF), gave itself several objectives:

Filling gaps in the island-wide economic fabric and secure paths to employment:

- by identifying the organic needs of the region's economy;

- by joined-up governance for stablely and sustainably areal development;

- by empowering all populations with opportunities to get training and basic vocational qualifications.

Serve, inform, guide, and support all populations on a fair and equal basis across the territory. Lending impetus to sandwich training:

- by strengthening ties among sponsor businesses, placement structures, and training centres;

- by promoting and expanding sandwich training solutions;

- by working to pre-empt early termination of training agreements;

- by scouting for new opportunities to leverage sandwich training prospects. 
Weaving the best quality practice into the training system:

- by giving training-offer professionals the training and tools they need for their service, information, guidance, and support roles;

- by engineering and optimizing the training infrastructure to deliver a local community-tailored training offer reaching out across the island and into the rural areas.

Progressively integrate Corsican language and culture across every echelon of vocational training and apprenticeship across the region, spearheaded by developing a Corsican-language certification scheme in every sector of training.

Facilitating employability and empowerment initiatives to get school-leavers and working-age people into work as part of a balanced and inclusive areal development policy.

These same objectives are also listed as strategic foundations written into the University of Corsica's 2015-2018 four-year objectives roadmap.

\section{The University of Corsica Sandwich-Placement System Tailored to a Small-Island Economy}

It is precise that University of Corsica sandwich-student school-to-work transition issue, reframed as pivotal to local regional development strategy, that the Corsica-region University-sponsored Placements \& Careers Service $^{2}$ (CFA-UNIV) aims to highlight as a real-world example of how to deal with specific constraints facing a small-island economy.

Corsica is an island economy marked by the complete absence of any of the big multinationals that fuel and forge the worldwide economy. What equally absent are any kind of medium-sized enterprises servicing big business that have spearheaded local economies in other regions like Lombardy. Corsica's economic fabric is essentially made up of small and home businesses, farm smallholdings, artisans, and small-scale retail.

Corsica also offers a case-in-point example of an areal region characterized by an ageing labour force making it necessary to realign mid-term regional vocational training strategy in response to this inescapable reality. As a major lever of local-regional development and social regulation policy, the island's vocational training system has to re-adapt its offer to achieve the targeted job-to-training fit. Continuing professional education and the sandwich-course system (apprenticeships, sandwich-course internships) are therefore the two core strands of the same policy platform designed to structure and build the competency levels, qualifications, and employability of the employed and unemployed labour force across a given territory.

In this setting, the CFA-UNIV is tasked with handling the promotion, development, and administrative-educative-financial management of the sandwich-course system at the University of Corsica (Ceccarini \& Storaï, 2011). Aligning its operational imperatives to the island's community fabric, it fosters initiatives designed to co-accommodate target populations (pure-graduate students, sandwich-placement students, and employees). This cross-fertilization framework makes it possible to capitalize innovative instructional practices while harnessing and networking the actors and agents (involve University of Corsica, CTC, businesses, community groups, local authorities, OPCA (government agencies handling subsidized professional training), jobsearch agencies, and the big chamber organizations) engaged in school-to-work training and transition.

\footnotetext{
2 Adopted by the University of Corsica governance council on 16 December 2008 and ratified by the Corsican Assembly on 30 January 2009.
} 
With commentators touting the knowledge economy as the only way out from endemic economic crisis, the CFA-UNIV has taken a pro-active role by engaging in a process to structure a consolidated, sustainable socio-economic fabric through optimized management of a vocational training/information, guidance services, and tailored careers support system for University of Corsica graduates.

\section{Ministry-Sponsored Surveys on the Transition-to-Work of University of Corsica Sandwich-Placement Students ${ }^{3}$}

For this purpose, a specific survey methodology designed to capture the school-to-work transition track record of University of Corsica sandwich-placement students was adopted as a performance instrument but also to provide statistical support to predictive policy building on directions that future vocational training efforts should take in order to fill human resources gaps in the Corsican socio-economic fabric. This predictive strand is a crucial factor, as the analyses produced are designed to guide the political (CTC) and institutional (the University) decision-makers in their coordinated effort to roadmap a vocational strand of Corsica-region's higher education geared to local-specific factors and variables.

The CFA-UNIV has thus conducted four annual surveys on the transition-to-work track record of University of Corsica students/graduates ${ }^{4}$ (Storaï \& Boulenger, 2012).

\section{Specifically-Tailored Methodology}

The specific survey methodology employed to capture the school-to-work transition track record of the sandwich-placement students (questionnaire send-out followed by telephone and email chase-up) afforded a mean response rate of $85.3 \%$ (i.e., 543 respondents out of 636 people surveyed over the four surveys) ${ }^{5}$, which is a statistically representative panel of the total population. The analyses developed are built around nine core focuses:

- Professional status of the student;

- Job level (occupational category);

- Time gap before integrating the current position;

- Contract type (long-term, short-term,...);

- In-job salary of the student;

- Job-to-training fit (whether the job position is an extension of curriculum completed);

- Geographic location of the job found;

- Structure taking on the sandwich-course leaver (businesses, community groups, and local authorities);

- Link to the initial sandwich-placement structure (are sandwich-placement students employed under the same roof?).

\footnotetext{
3 The CFA-UNIV conducts the annual apprenticeship-to-work transitions (IPA) survey specific to University of Corsica sandwich-placement students (tracking transition to employment of all (graduate or non-graduate) sandwich-course leavers as of March the following year).

4 The CFA-UNIV has led four apprenticeship-to-work surveys on the transition-to-work track record of sandwich-course leavers in 2011, 2012, 2013, and 2014. The term leaver refers to where the student surveyed currently stands: he/she either (i) graduated from the last vocational training course they attended, left school and is currently in (or looking for) work, or (ii) failed to graduate or dropped out mid-year and does not envisage going back to school. The student is therefore currently in (or looking for) work.

5 Exact figures put the survey response rates from the sandwich-placement students concerned at $87.8 \%$ in 2011 (157 respondents out of 179 surveyed), $82.5 \%$ in 2012 (99 respondents out of 120 surveyed), $84.4 \%$ in 2013 (151 respondents out of 179 surveyed) and $86.1 \%$ (136 respondents out of 158 surveyed).
} 


\section{A Panel of Characteristic University of Corsica Vocational Curriculum Courses}

The University of Corsica's vocational curriculum courses surveyed illustrate five core activity areas representative of university teaching opened up to directly fill gaps in the island-wide socio-economic fabric:

- Management: DUT (university technical diploma) in Business and Administrative Management (DUTGEA), LP (national professional-vocational bachelor's degree) in Entrepreneurship (LPE), Banking, Masters degrees in Business Administration, Human Resources, Regional Development Engineering, Sustainable Tourism Management, and Marketing;

- Business: DUT in Marketing Techniques, LPs in Business-Marketing \& Communication, Tourism - Hotel \& Catering, and Marketing Tourism Products;

- Computing and Communications: DUT in Multimedia and Internet Technology, LP in Communication techniques and Channels, DU (university-issue degree diploma) in Audiovisual Engineering, masters degrees in Internet \& Information Systems, Landscapes, Heritage \& Media in Europe and the Mediterranean, and Cultural Product Engineering;

- Industry: DUT in Civil Engineering, Biological Engineering (biotech \& food-farming industries), DEUST (university science and technology diploma) in Environmental Biology Analysis, LPs in Civil Engineering and Construction Work, Electricity, Electronics and Industrial Systems, and masters degree in Mediterranean Food-Farming Systems Engineering;

- Environmental Science: DUT in Biological Engineering (environmental engineering), Health-Safety-Environment, LP Water and Environmental Governance, Health-Safety-Environment-Quality, Energy \& Climate Engineering-Renewable Resource Management, masters degrees in Energetics \& Reenwable Energies, Water and Environmental Science, Integrative Management of Coastline, Ecosystems and Major Hazard Control, and Ecological Engineering.

In total, 34 applied vocational courses were targeted, counting 889 students including 287 sandwich-placement students. ${ }^{6}$

\section{Moving From Expected Outcomes to Predictive Values Ready to Devise a Regional Human Capital Development Policy}

Stemming from the University of Corsica's ministerial accountabilities (nationally-coordinated regional-scale survey led by universities offering a broad-spectrum vocational development curriculum), the CTC, is simultaneously exercising its mission to promote regional apprenticeship schemes and its mission to validate the map of regional-scale coverage of training programmes ${ }^{7}$, commissions of the University of Corsica (via the CFA UNIV) annually provide tangible figures on graduation rates and school-to-work transition record to inform and shape political policy decisions on the island's CPRDF roadmap.

This tool, wielded by regional government, informs mid-term regional vocational training policy and the aligned coordination of the vocational training paths on offer. To forge this regional plan, the CTC relies on active input from Corsica's educative, economic, and social community networks.

\section{Report and Analysis of the Main Findings}

The raw data and the findings reported here are taken from the four apprenticeship-to-work surveys

\footnotetext{
6 Four-year average.

7 See earlier under point 1.
} 
(Figure 1) conducted by the CFA-UNIV ${ }^{8}$.

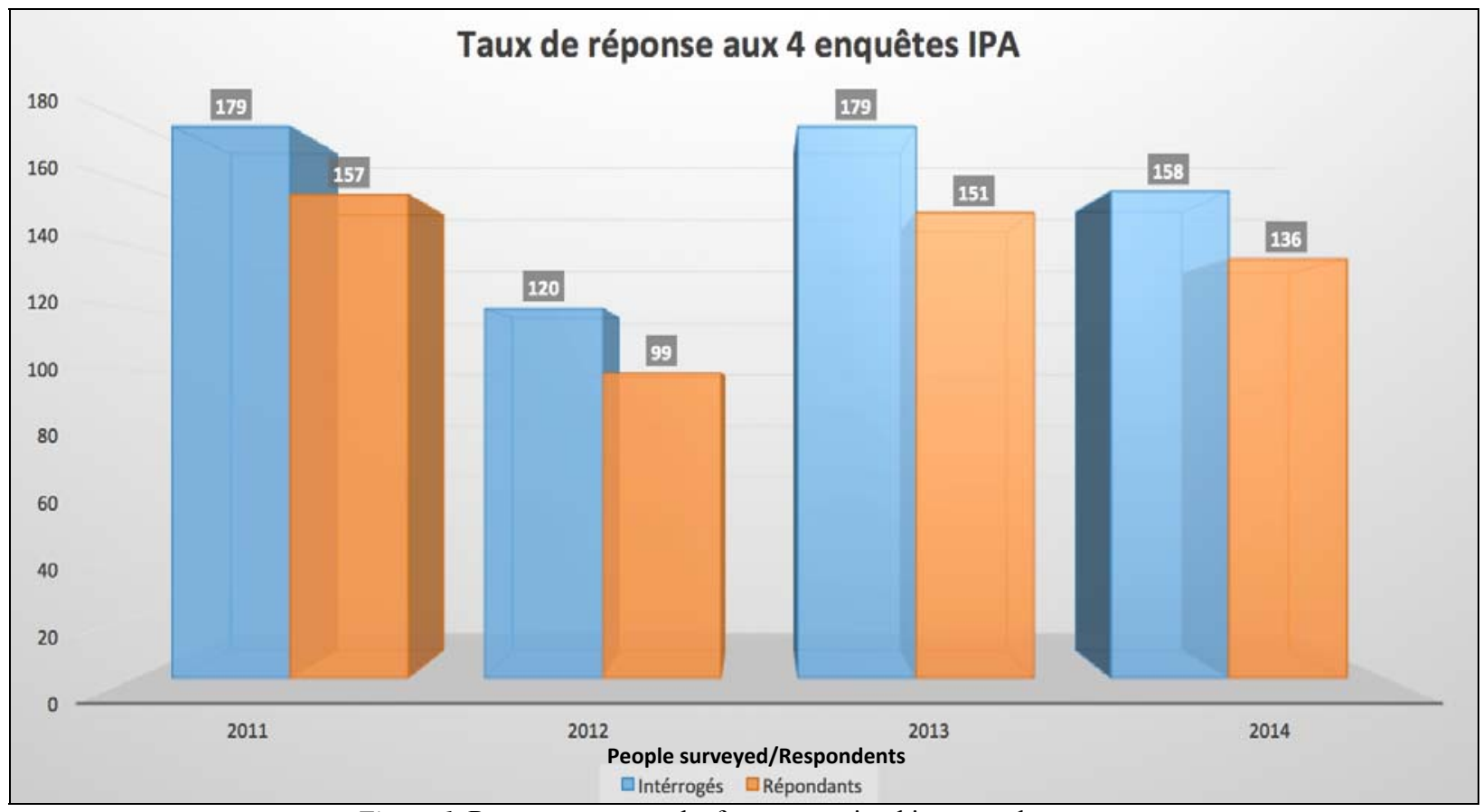

Figure 1. Response rates to the four apprenticeship-to-work surveys.

Distribution of sandwich-placement students broken down by diploma (Figure 2):

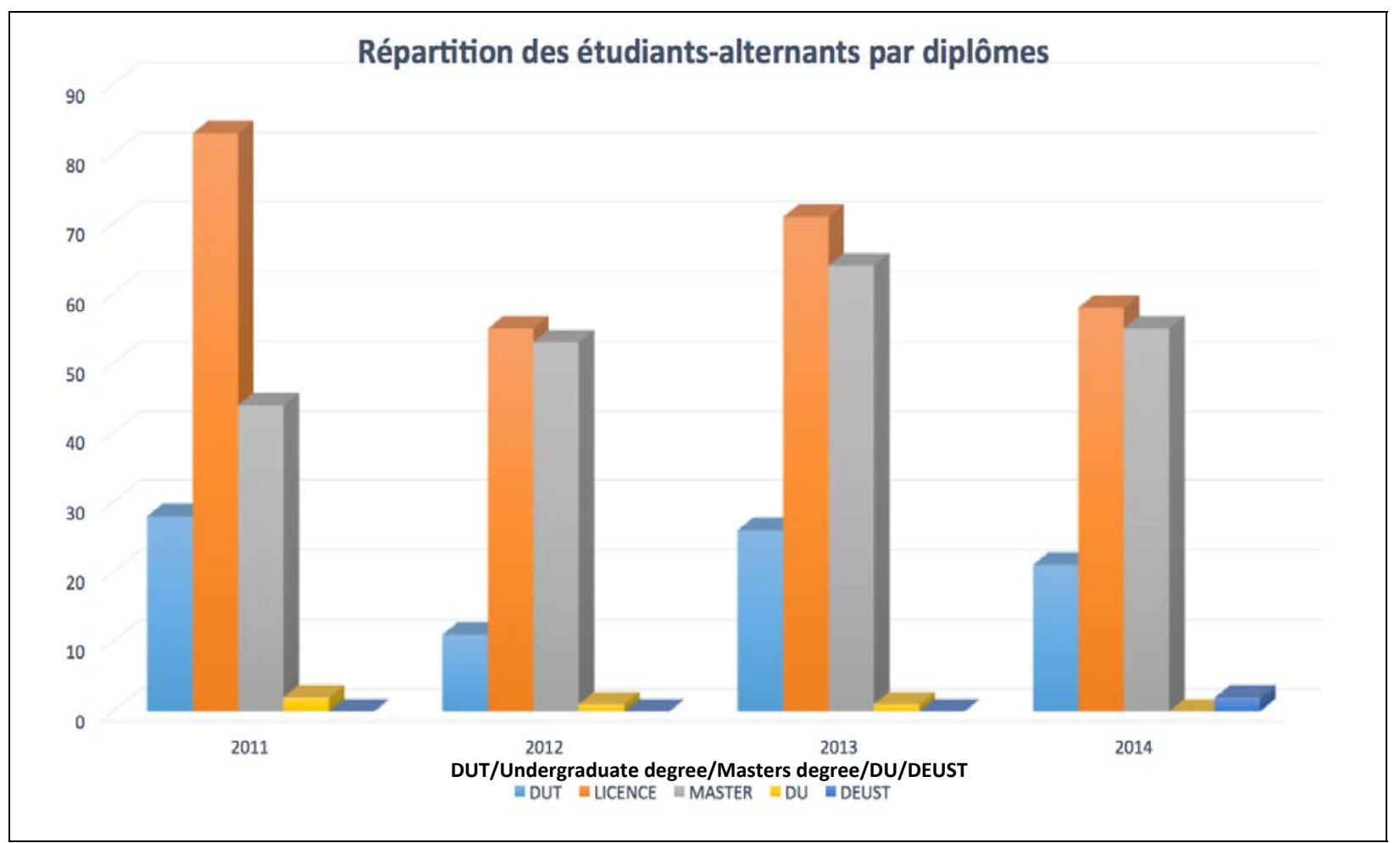

Figure 2. Distribution of sandwich-placement students broken down by diploma.

\footnotetext{
${ }^{8}$ See earlier under point 4.
} 
Career situation of sandwich-course leavers (Figure 3):

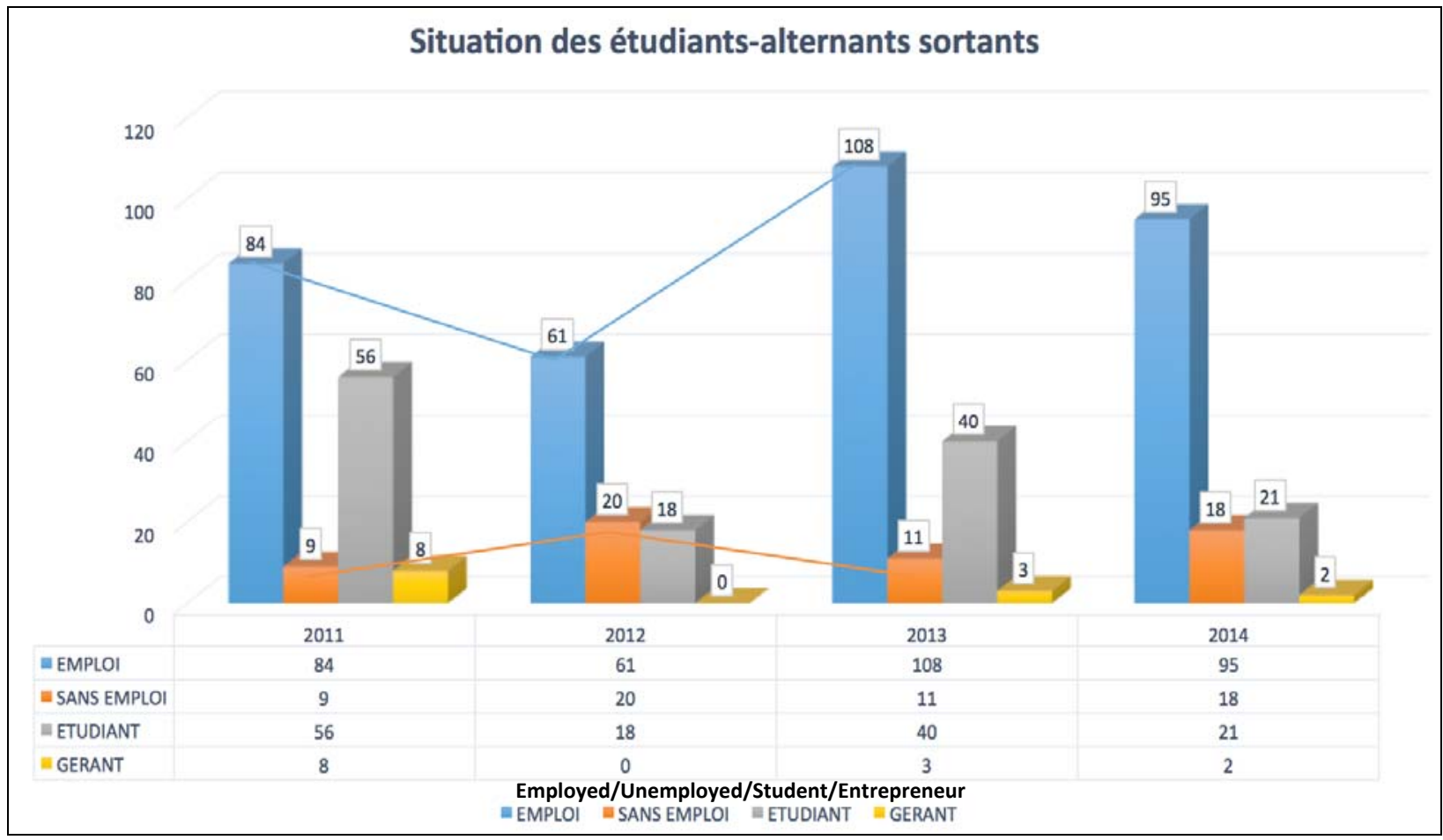

Figure 3. Career situation of sandwich-course leavers.

Types of job contracts held by sandwich-course leavers (Figure 4):

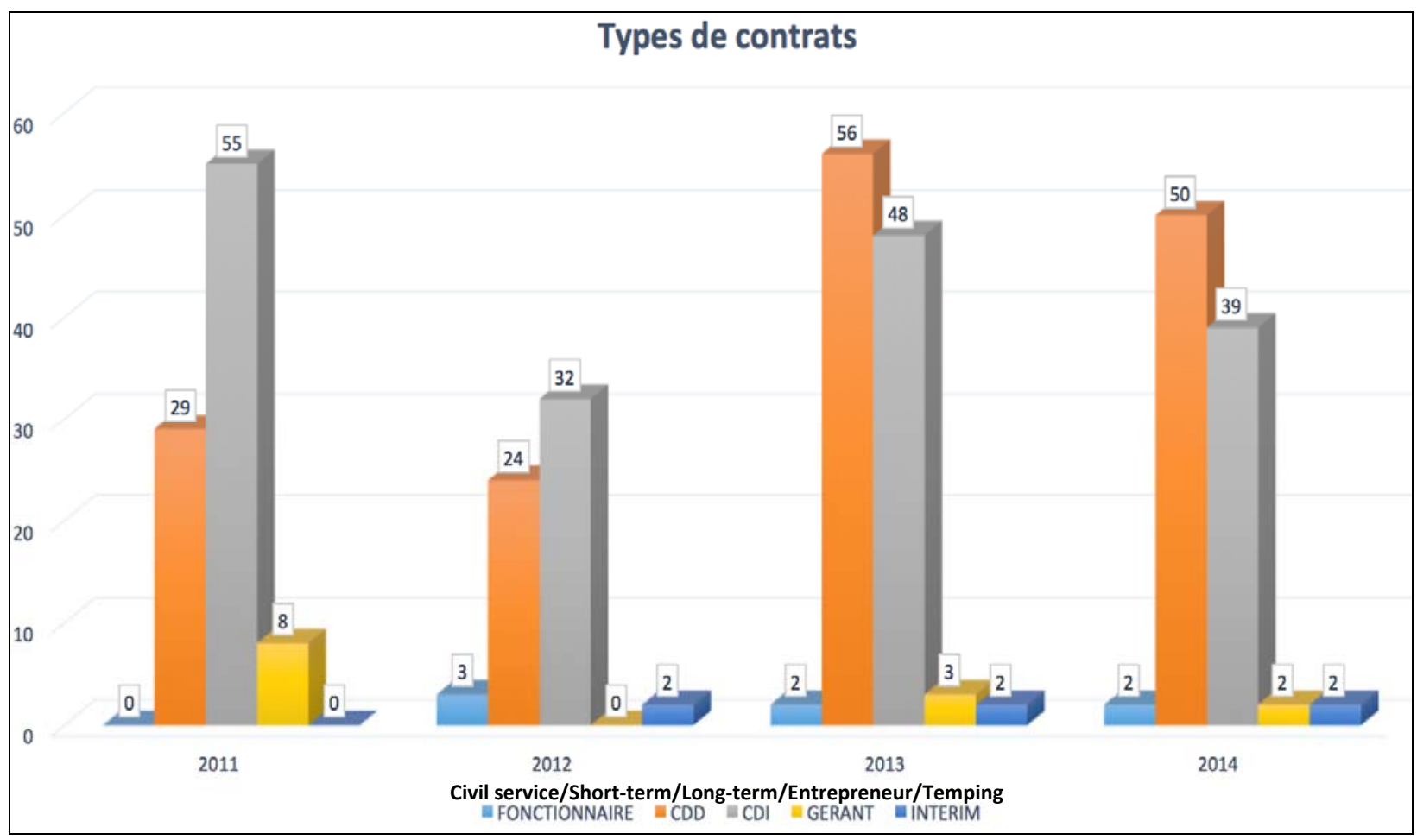

Figure 4. Types of job contracts. 
Types of occupational categories held by sandwich-course leavers (Figure 5):

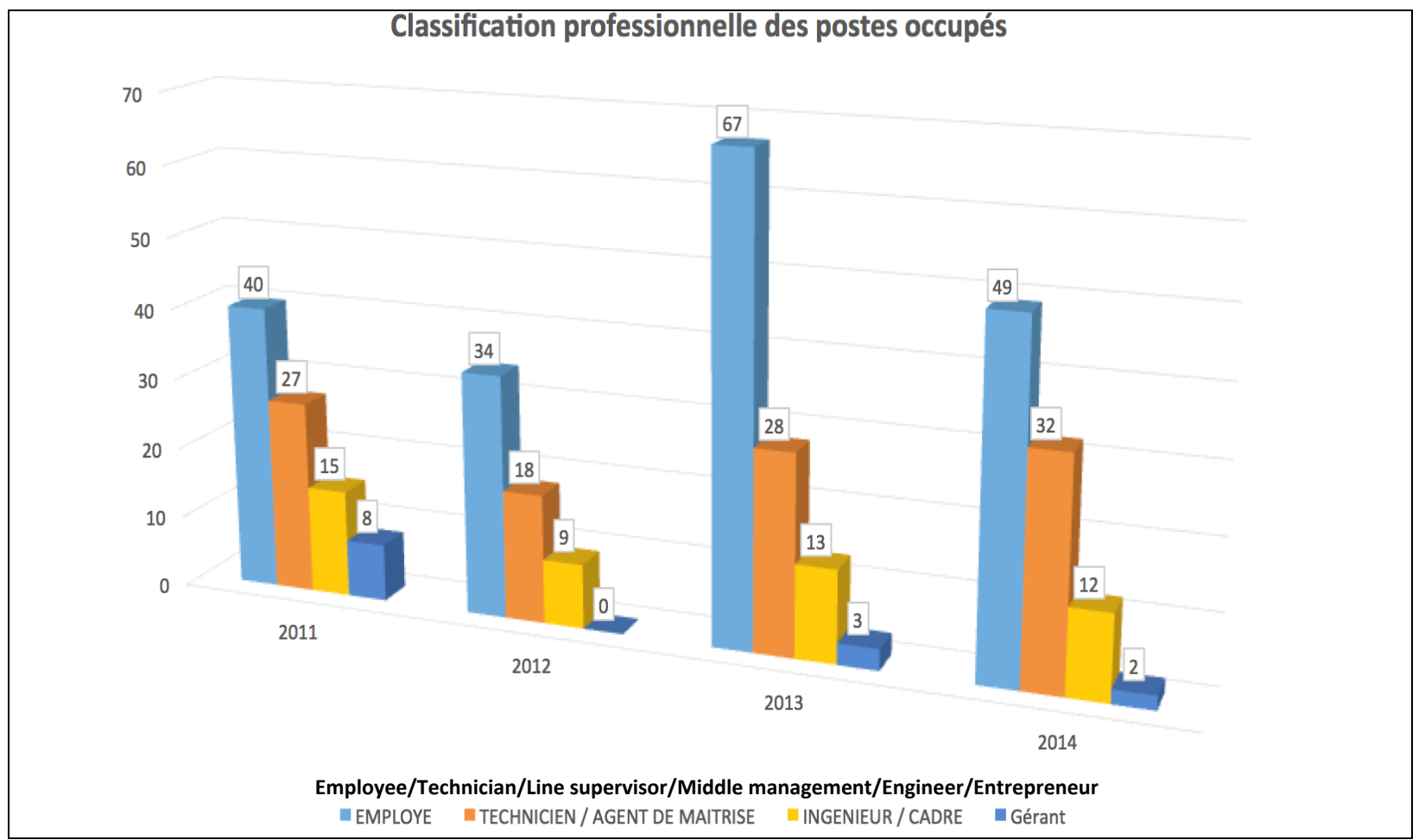

Figure 5. Professional classification of the jobs held.

Job-to-training fit for sandwich-course leavers (Figure 6):

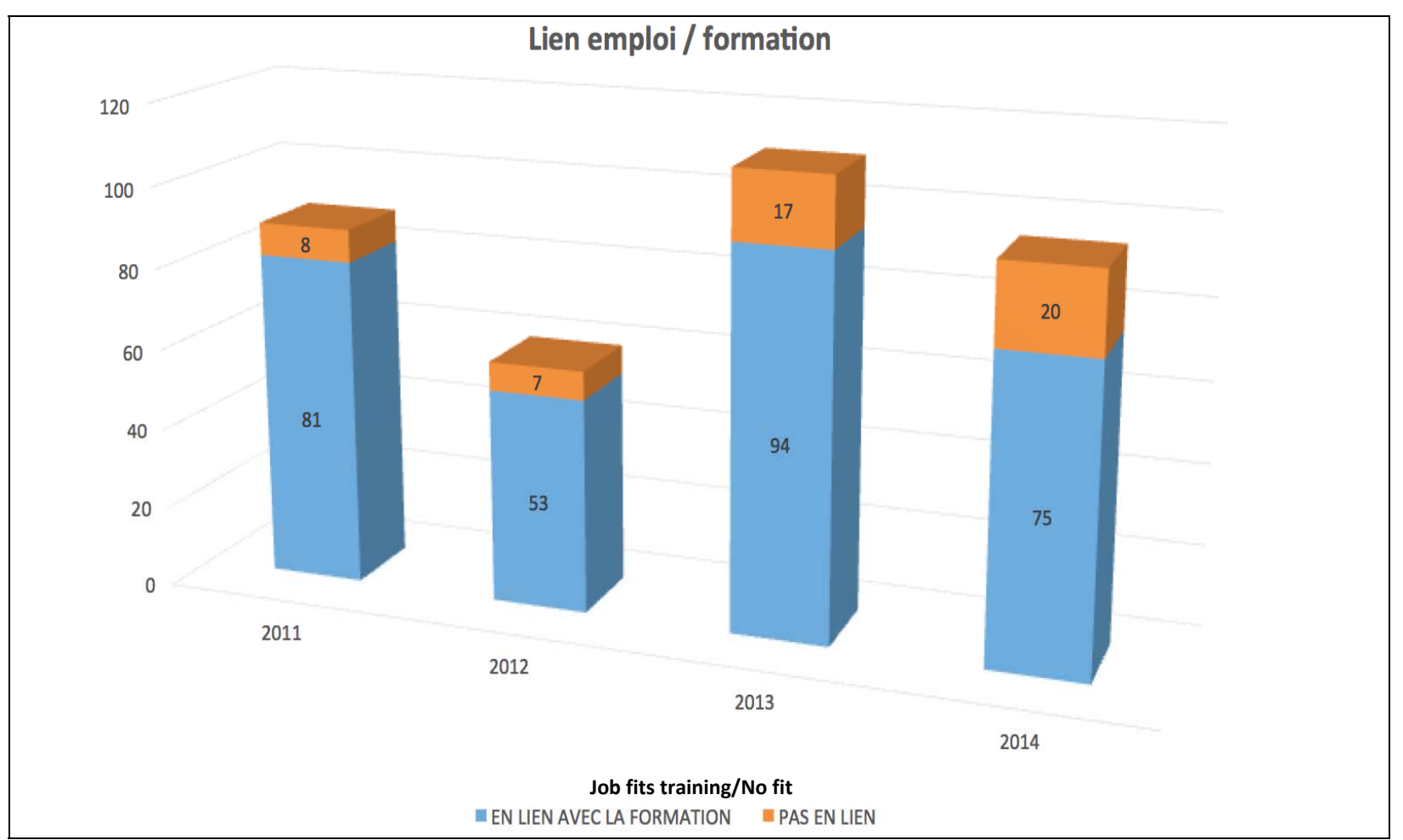

Figure 6. Job-to-training fit. 
Type of structures taking on sandwich-course leavers (Figure 7):

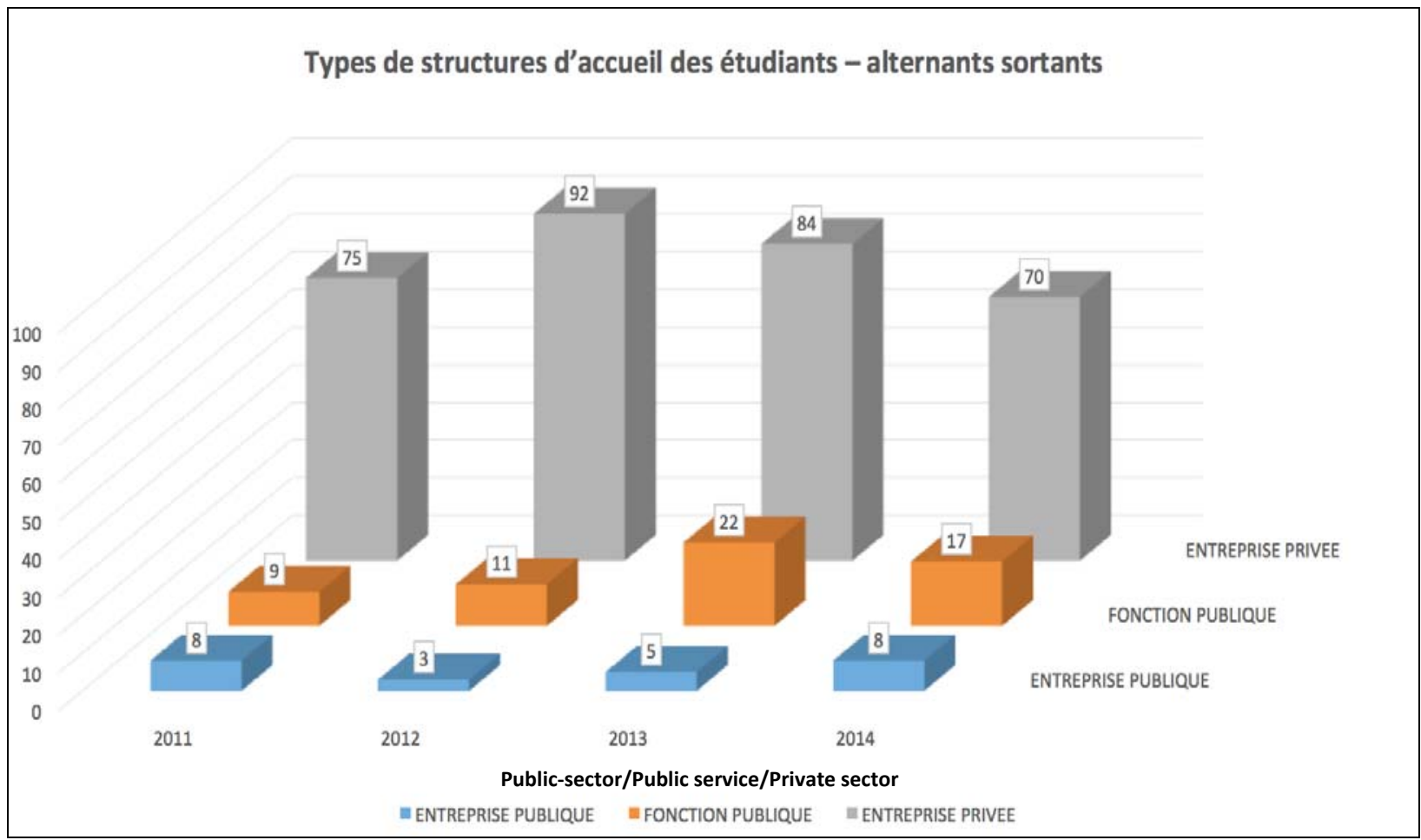

Figure 7. Type of structures taking on sandwich-course leavers.

Size of structures taking on sandwich-course leavers (Figure 8):

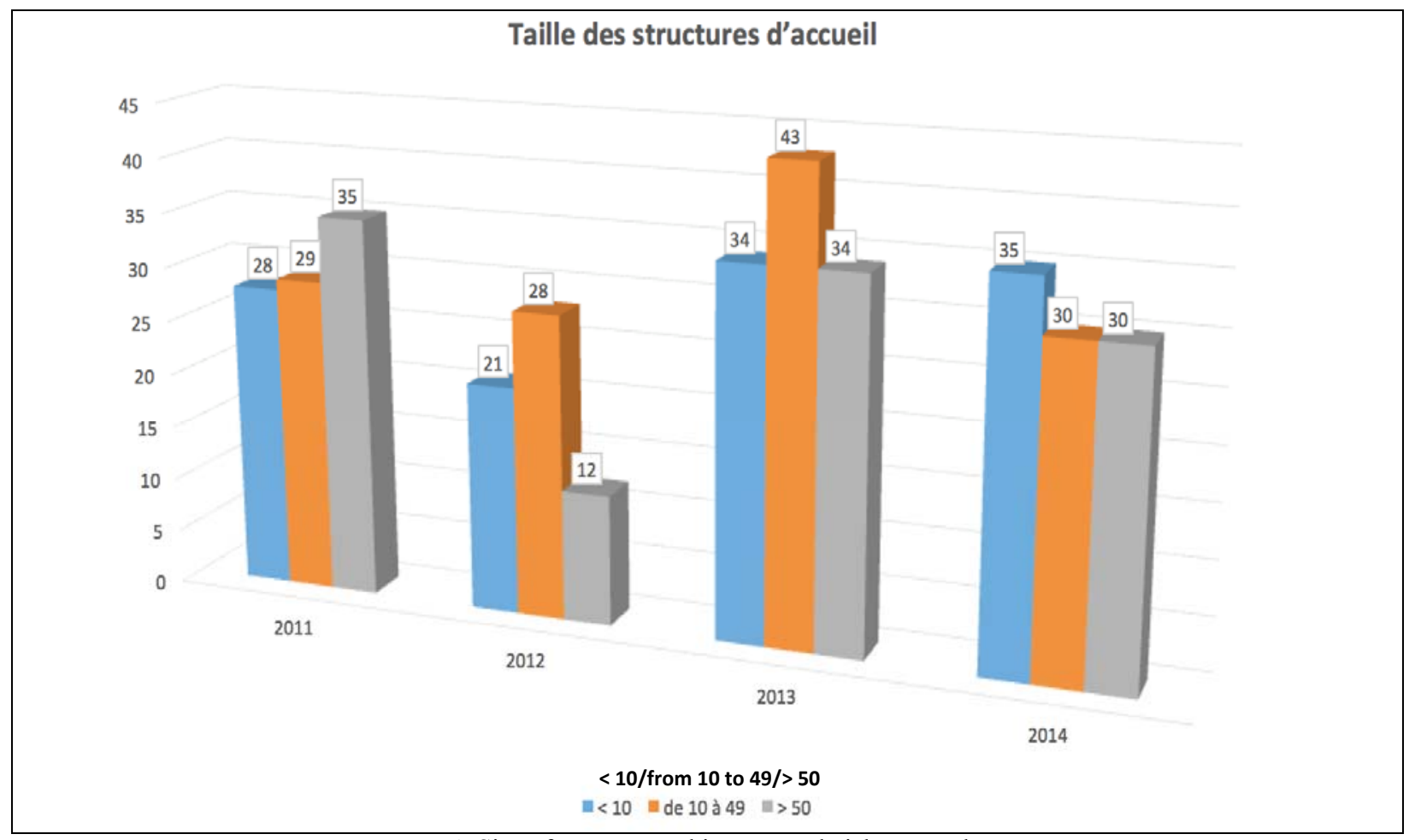

Figure 8. Size of structures taking on sandwich-course leavers. 
Geographic location of jobs found by sandwich-course leavers (Figure 9):

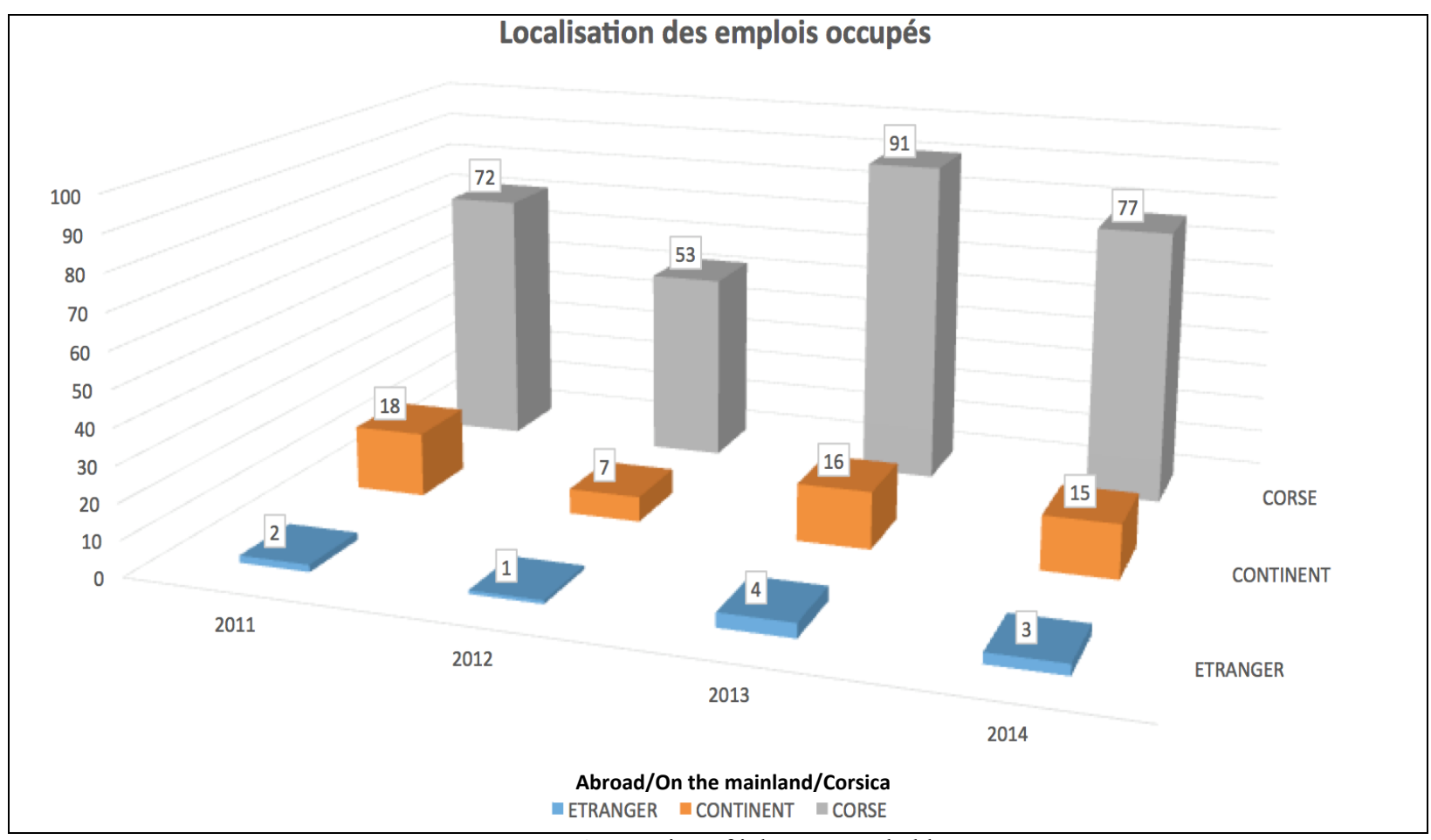

Figure 9. Location of job contracts held.

Salary brackets of job contracts held by sandwich-course leavers (Figure 10):

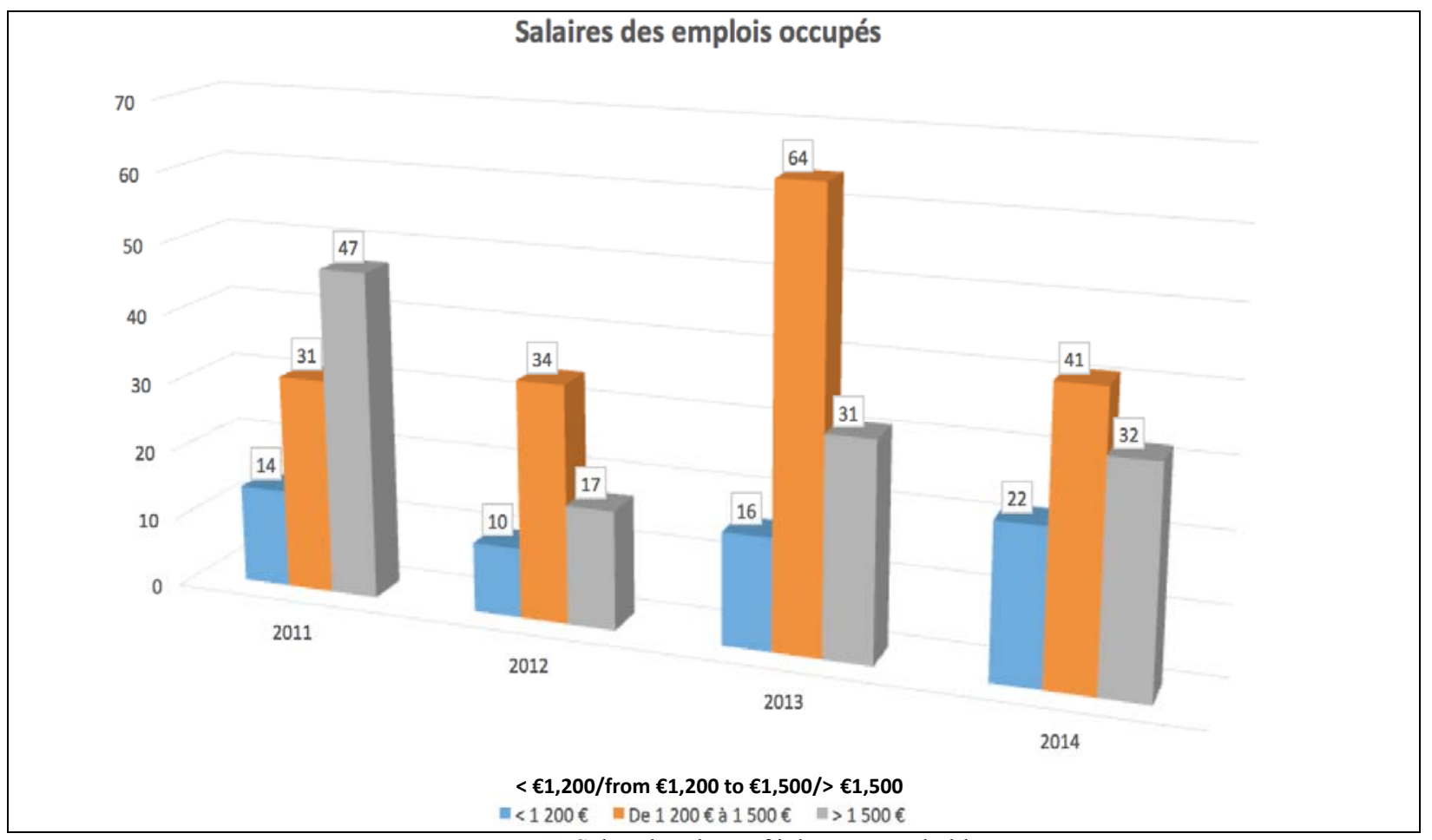

Figure 10. Salary brackets of job contracts held. 
Examples of the kinds of jobs held by sandwich-course leavers:

- sales representative;

- accountant;

- research officer;

- project site supervisor;

- web designer;

- laboratory technician;

- construction superintendent;

- network leakage technician;

- PR assistant;

- customer support assistant;

- PR officer;

- client services advisor;

- quality control specialist;

- risk prevention engineer...

Situation of sandwich-course leavers continuing in education at another faculty (Figure 11):

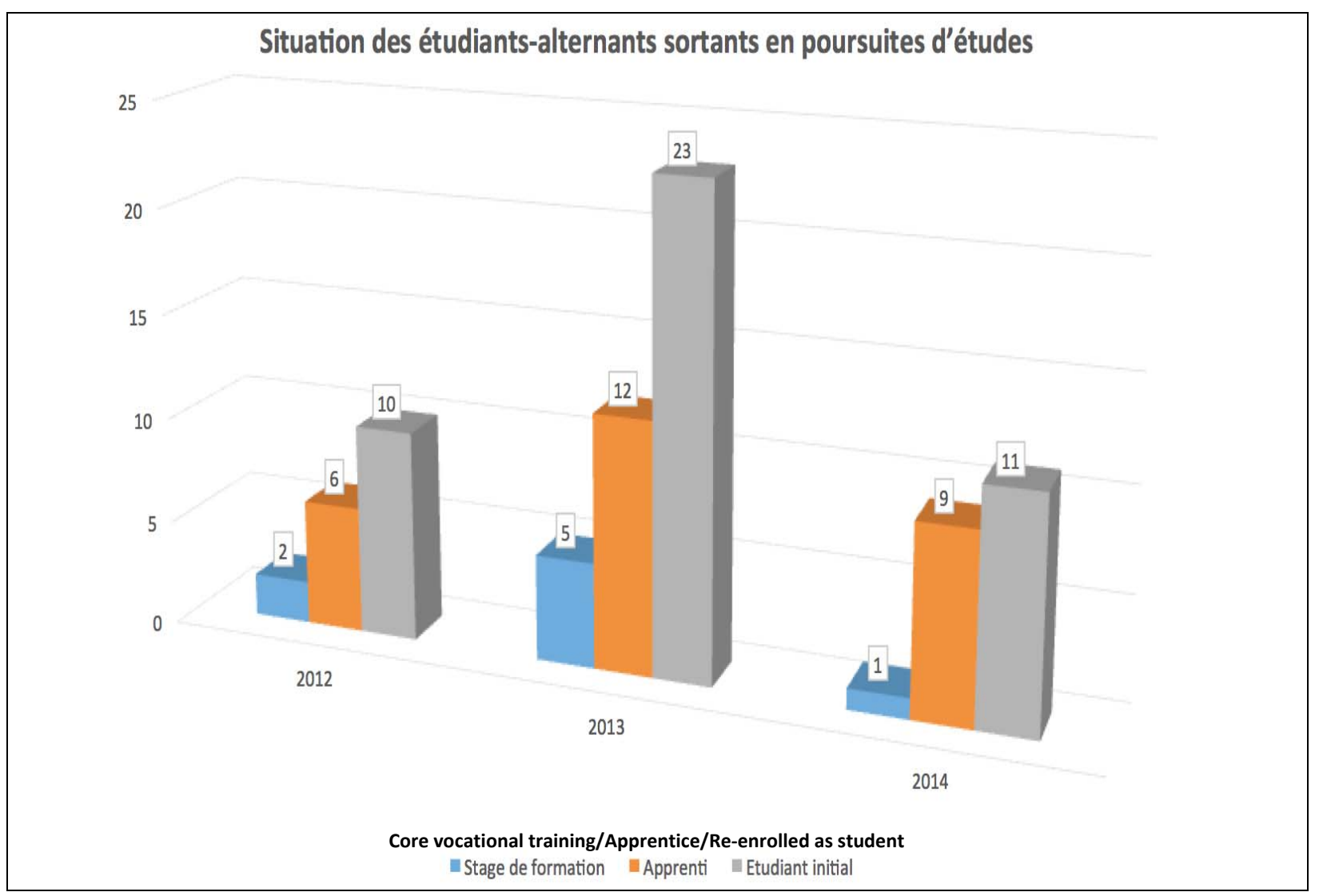

Figure 11. Situation of sandwich-course leavers continuing in education. 
Reasons pushing sandwich-course leavers to continue education at another faculty (Figure 12):

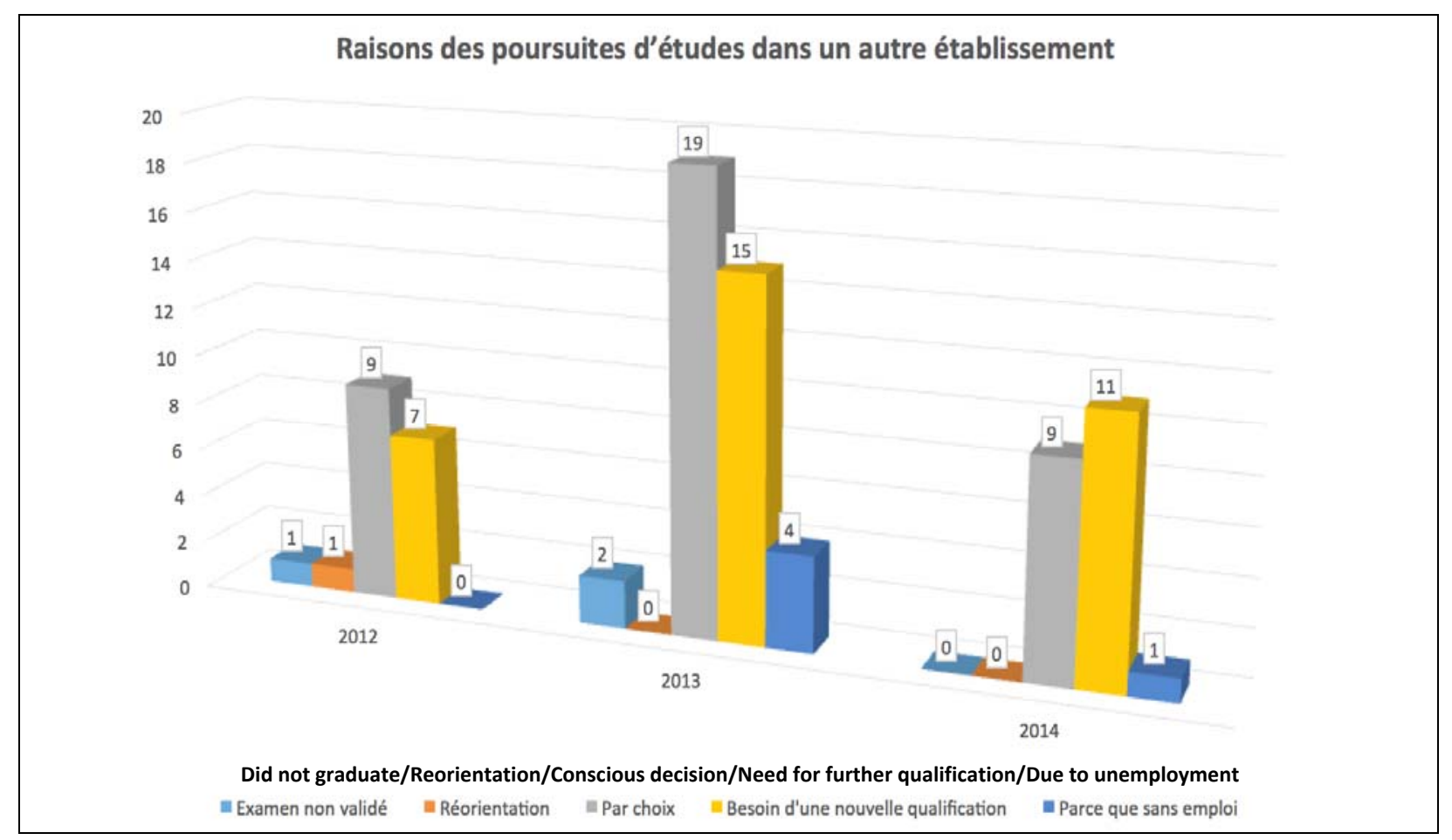

Figure 12. Reasons pushing sandwich-course leavers to continue in education at another faculty.

The findings of the four CFA-UNIV-led apprenticeship-to-work surveys provide the island's public policymakers with concrete figures and trendlines that can help shape a general roadmap for regional human capital development and a targeted regional policy strategy for vocational training in higher education.

A handful of key figures paint this picture clearly:

- $67 \%$ of sandwich-course leavers are in employment at six months after the last vocational training course attended (Figure 3);

- $86 \%$ of job contracts held fit the vocational training course(s) attended, with $82 \%$ located in Corsica (Figure 9);

- $53 \%$ of job contracts held are sustainable employment prospects, of which $6 \%$ try to sustainable entrepreneurship projects (Figure 4);

- $35 \%$ of these positions correspond to a take-home monthly salary (before bonuses) of over $€ 1,500$ (Figure $10)$

- $89 \%$ of decisions to continue in education were driven by personal reasons and a need for further qualifications, with only $7 \%$ prompted by failing to find a job (Figure 12);

- $69 \%$ of job contracts held are in microenterprises and small businesses, in line with the structured entrepreneurial fabric of Corsica's island economy (Figure 9).

The University of Corsica sandwich-placement system is not just a gateway into employment but also a pathway to excellence, as $75 \%$ of graduates completing the 34 all-population courses (pure-graduate students, sandwich-placement students, and employees) are sandwich-placement students. 


\section{Conclusion}

The survey's findings point to particularly encouraging signs on employability and quality of school-to-work transition of University of Corsica students, especially in the analysis of targeted job-to-training fit (Storaï, Rinieri, \& Boulenger, 2014). This grass-roots reality opens up promising future perspectives for a structured entrepreneurial fabric in Corsica built on the sandwich-course system platform where placement businesses are centrally empowered to train up young local talent.

Ultimately, the overriding objective remains to successfully coordinate the impetus given to vocational training as a solution to fill gaps in the island-wide socio-economic fabric (maximization of the job-to-education fit) through the emergence of sandwich-course training channels (levels III, II, and I) ${ }^{9}$. Moving towards this objective, the findings of the CFA-UNIV apprenticeship-to-work surveys provide regional public policymakers with positive concrete guidance.

From this perspective, the expertise of CFA-UNIV brings insights that are liable to guide strategic decisions on vocational training policy, employment policy, and how to structurally shape the island as a social and economic area (Furt \& Storaï, 2011). These findings will be presented as part of a wider initiative to build a regional human capital development policy decision support tool focused on the theme of areal planning and regional branding for Corsica.

\section{References}

Ceccarini, A., \& Storaï, C. (2011). The alternation in the higher education: An excellent way and a footbridge towards the employment, the teachings of the University Vocational Training in Corsican region. Proceedings from XVIème colloque CNR IUT, Cherbourg-Octeville, 8-10 June.

Colletis, G., \& Pecqueur, B. (1996). Firms and territories: Between nomadism and anchoring (Firmes et territoiresv: Entre nomadisme et ancrage). Revue Espaces et Sociétés n spécial, 2, 110-117.

Furt, J. M., \& Storaï, C. (2011). Which social organisation for a patrimonial economy? (Quelle organisation sociale pour une économie patrimoniale?). In A. Fazi and J. M. Furt (Eds.), Vivre du patrimoine (pp. 401-409). Edition l'Harmattan.

Marchesnay, M., Kammoun, S. C., \& Karray, H. E. (2006). Is there a mediterranean entrepreneurship (Y-a-t-il un entrepreneuriat méditerranéen?)? Revue Française de Gestion, 32(166), 132-147.

Storaï, C., \& Boulenger, M. (2012). The occupational integration of the graduate students of the University of Corsica: A strategic stake at the heart of the dynamics of the Corsiacn territorial development. 19th IBIMA Conference, Barcelona, Spain 12-13 Nov.

Storaï, C., Rinieri, L., \& Boulenger, M. (2014). Sandwich-course training in higher education as a major strategic thrust regional policy of professional training: Lessons learned from the pioneering example of the University Institute of Technology Corsica. Chinese Business Review, 13(2), 101-110.

Veltz, P. (1997). Globalization, cities and territories: The economy of the Archipelago. Paris: PUF.

\footnotetext{
9 i.e., the National Classification of Levels of Training used, especially for statistical purposes, as a metric of educational attainment. Skill level III is for staff with a job normally requiring a DUT or a Brevet de Technicien Supérieur (BTS) or end of undergraduate higher education. Skill level II is for a person with a middle management job that normally requires Bachelor's degree or LP-level training. Skill level $I$ is for a person with a middle management job that normally requires a training above the first-year Master's degree level.
} 